\title{
The Soil Heavy Metal Information Accurate Collection and Evaluation about Lycium Barbarum Cultivation in Western China
}

\author{
Ming Xiao ${ }^{1,2}$, Wenjun Yang ${ }^{2}$, Ze Zhang ${ }^{1}$, Xianglin Tang ${ }^{1}$, Xin Lv ${ }^{1, *}$, \\ and Dezhao $\mathrm{Chi}^{2}$ \\ ${ }^{1}$ Shihezi University Agriculture College, Xinjiang 832000 China \\ ${ }^{2}$ Qinghai Agriculture and Forestry Academy of Sciences, Qinghai 810016 China \\ \{mhmdxiao, ndyxiaozhun\}@163.com, \{273160043,123452741\}@qq.com \\ 1xshz@126.com, qaafcdz@sina.com
}

\begin{abstract}
We selected two small sections of Lycium Barbarum cropland at Nuomuhong Farm in the Qaidam basin, western China: one had been farmed for only one year (original land), and the other had been farmed for many years (farm land). We tested surface soil samples for their content and distribution of six heavy metals $(\mathrm{Cd}, \mathrm{Zn}, \mathrm{Pb}, \mathrm{Cu}$, As, and $\mathrm{Cr})$. All six heavy metals appeared at medium levels in samples from both sections of cropland. We conducted an interpolation analysis and drew a spatial distribution map based on the inverse distance weight (IDW) method. The distribution graph revealed a relatively consistent distribution of the six heavy metals in soil samples, a different gradation in the original land, and areas of higher values in the farm land. These findings suggest that the soil had been polluted. According to the Pollution-Free Food Standard and the Green Food Standard, we calculated the integrate pollution index using the Nemerow index method to check whether the levels met Pollution-Free food Standard and Green Food Standards. The values were 0.5 and 0.7 (defined as 'clean') in samples from the original land, but were 0.6 and 0.9 in samples from the farm land, which may be considered excessive.
\end{abstract}

Keywords: assessment, heavy metal pollution, standard, Lycium barbarum, Qaidam.

\section{Introduction}

Under heavy metal pollution, crop soils may exhibit latency, chronicity, irreversibility, and have strong toxic properties and abiotic degradation. This is an important challenge for producers of high-quality agricultural products and researchers in the fields such as edaphology, resource environmental protection, and agricultural product quality safety. Investigations of spatial variations in heavy metals, which are important to evaluating soil environmental quality and heavy metal pollution, involve analyzing spatial features

* Corresponding author. 
including the content of heavy metals, along with any changes, trends, and spatial variation in those metals[1]. Recently, researchers have combined geographic statistics with geographic information system (GIS) data to analyze regional environmental processes. Mingkai Qu, Weidong Li and Chuanrong Zhang has assessed the spatial distribution and uncertainty of the potential ecological risks of heavy metals in soil using sequential Gaussian simulation (SGS) and the Hakanson potential ecological risk index (PERI) in Wuhan, China. Results show that the potential ecological risks of Cr, $\mathrm{Cu}, \mathrm{Pb}$, and $\mathrm{Zn}$ are relatively low in the study area, but $\mathrm{Cd}$ indeed reaches a serious level that deserves much attention and essential treatment[2]. Linsen Zhang, Jun Liang, Chunlin $\mathrm{Wu}$ et al. evaluated the contents of $\mathrm{As} \mathrm{Pb} \mathrm{Cr} \mathrm{Cd}$ and $\mathrm{Cu}$ in an apple-planting region in Shanxi province using a method that incorporated a single pollution index and a comprehensive pollution index according the Green Food Standard, show that the heavy metals were not accumulated gradually in old apple orchards and all meet the standards[3]. Gailin Wu, like li, Mingde Hao et al. on the basis of the integrate pollution index of heavy metal research proposed fertilizer application should pay attention to the content of heavy metals in fertilizer, a reasonable choice, in order to avoid the contamination of the soil environment[4]. Xia Huang, Tingxuan Li and Haiying Yu. used a signal pollution index and the Nemerow composite index to evaluate the heavy metals risk, and the results show that there was Cd contamination in greenhouse topsoils in Shouang Shandong Province[5].

The Qaidam basin, located on the Tibetan Plateau, is a closed region and few studies have assessed environmental effects in the area of reclamation. No studies have investigated the spatial variation in heavy metals or their potential pollution risk in soils in the planting region of Lycium barbarum (common names: goqi berry, wolfberry, medlar).

\section{Experiments and Methods}

\subsection{Experimental Samples}

\subsubsection{Study Area Overview}

The Qaidam Basin is located on the edge of the Tibetan Plateau, surrounded by the Kunlun, Qilian, and Altun Mountains. Nuomuhong Farm is located southeast of the basin at altitudes ranging from $2700 \sim 3000 \mathrm{~m}$. It is irrigated by snow waters from the Kunlun Mountains, which enables oasis farming. The area is cold and dry with little rainfall, abundant sunlight, and large differences between daytime and nighttime temperatures. Soil in the area has $\mathrm{PH}$ values ranging from $7.8 \sim 8.2$. Because the area is mostly sandy loam and has few plant diseases and insect pests, it is suitable for growing L. barbarum, and the L. barbarum produced in this area is famous for its quality and is quite valuable [6].

\subsubsection{Soil Sample Collection, Tests, and Data Processing}

Sample Collection: Samples were collected based on the following guiding principles: Select cultivated farmland in flat areas (avoid depressions or mounds). Try to avoid non-representative areas, e.g., those that have been altered by human activity or where soil has greatly eroded. Do not collect samples from areas currently being fertilized. Try to collect samples 30 days before or after fertilization. 
The farm land field was a rectangular area of $660 \mathrm{~m} \times 510 \mathrm{~m}$, and the original land was a rectangular area of $400 \mathrm{~m} \times 330 \mathrm{~m}$. We adopted the grid soil sampling method and selected samples at $100 \mathrm{~m} \times 50 \mathrm{~m}$ intervals. A dot in each interval served as a center point; we randomly selected five points, each with a $3 \mathrm{~m}$ radius. We then took a $20 \mathrm{~cm} \times 20 \mathrm{~cm} \times 20$ $\mathrm{cm}$ cube of soil from each point. From these samples, we took $1 \mathrm{~kg}$ from each and created a mixed sample by equally mixing the $1 \mathrm{~kg}$ samples from all the sites. The samples were taken to our lab for analysis. We recorded the fixed position sampling point coordinates using GPS. In order to prevent sample contamination, we did not let the samples touch metal containers during sample collection, preservation, and processing.

Sample Testing: Stones, grass roots, and other plant residues were removed from the samples, which were left to dry in a ventilated room. Samples were then filtered using a 100 mesh sieve (150 um mesh size). A MILESTONE brand microwave digestion instrument was used, along with an inductively coupled plasma emission spectrometer.

The testing method involved using $7 \mathrm{ml}$ (top grade and pure) concentrated nitric acid, $2 \mathrm{ml}$ (top grade and pure) hydrogen peroxide, and $2 \mathrm{ml}$ (top grade and pure) hydrofluoric acid. Standard substances of these chemicals were purchased from the National Standard Substance Center; for the standard curve, we used three density gradients of $0,0.5$, and 1 and a unit of $\mathrm{mg} / \mathrm{l}$.

\subsubsection{Data Processing}

The data were entered into Excel and subjected to the inverse distance weighting (IDW) method. A spatial analysis was conducted and the results were presented using ARCGIS9.3.

\subsubsection{Heavy Metal Soil Pollution Assessment Method}

Single pollution index evaluation: For the evaluation, $\mathrm{P}_{\mathrm{i}}=\mathrm{C}_{\mathrm{i}} / \mathrm{S}_{\mathrm{i}}$, where $\mathrm{P}_{\mathrm{i}}$ is the i single pollution index of a pollutant, $C_{i}$ is the $i$ actual measurement, and $S_{i}$ is the evaluation standard for the pollutant. The evaluation standard was calculated separately in accordance with the industrial standards of "Pollution-Free Food standard" (NY/T 5249-2004) [7] (Table 1), and "Green Food Standard" (NY/T 391-2000) [8] (Table 2). Values of $\mathrm{P}_{\mathrm{i}}<1$ for $\mathrm{As}, \mathrm{Hg}, \mathrm{Cd}, \mathrm{Cr}$, and $\mathrm{Pb}$ indicate that the soil is not polluted, and the sample meets environmental standards. If one or more elements has a value of $\mathrm{P}_{\mathrm{i}}>1$, the soil is polluted and does not meet environmental standard.

Table 1. Pollution-Free Food standard (NY/T 5249-2004). Heavy metals: mg/kg

\begin{tabular}{rllll}
\hline & \multicolumn{4}{c}{ Grade level } \\
\cline { 2 - 5 } Item & \multicolumn{2}{c}{ Grade I } & \multicolumn{3}{c}{ Grade II } \\
\cline { 2 - 5 } & Background & $<6.5$ & $6.5 \sim 7.5$ & $>7.5$ \\
\hline $\mathrm{Cd} \leq$ & 0.20 & 0.30 & 0.30 & 0.60 \\
$\mathrm{Hg} \leq$ & 0.15 & 0.30 & 0.50 & 1.0 \\
$\mathrm{As} \leq$ & 15 & 40 & 30 & 25 \\
$\mathrm{Cu} \leq$ & $/$ & 150 & 200 & 200 \\
$\mathrm{~Pb} \leq$ & 35 & 250 & 300 & 350 \\
$\mathrm{Cr} \leq$ & 90 & 150 & 200 & 250 \\
$\mathrm{Zn} \leq$ & 100 & 200 & 250 & 300 \\
\hline
\end{tabular}


Table 2. Green Food Standard (NY/T 391-2000). Heavy metals: mg/kg

\begin{tabular}{lllllll}
\hline Farming condition & Dry field & \multicolumn{4}{c}{ Paddy field } \\
\hline $\mathrm{PH}$ & $<6.5$ & $6.5-7.5$ & $>7.5$ & $<6.5$ & $6.5-7.5$ & $>7.5$ \\
$\mathrm{Cd} \leq$ & 0.30 & 0.30 & 0.40 & 0.30 & 0.30 & 0.40 \\
$\mathrm{Hg} \leq$ & 0.25 & 0.30 & 0.35 & 0.30 & 0.40 & 0.40 \\
$\mathrm{As} \leq$ & 25 & 20 & 20 & 20 & 20 & 15 \\
$\mathrm{~Pb} \leq$ & 50 & 50 & 50 & 50 & 50 & 50 \\
$\mathrm{Cr} \leq$ & 120 & 120 & 120 & 120 & 120 & 120 \\
$\mathrm{Cu} \leq$ & 50 & 60 & 60 & 50 & 60 & 60 \\
\hline
\end{tabular}

Nemerow pollution index evaluation: In $\mathrm{P}_{\mathrm{N}}=\left(\left(\mathrm{P}_{\mathrm{i}}^{2}+\mathrm{P}_{0}^{2}\right) / 2\right)^{1 / 2}, \mathrm{P}_{\mathrm{N}}$ is the Nemerow composite index, $\mathrm{Pi}$ is the average pollution index for the soil, and $\mathrm{P}_{0}$ is the maximum pollution index of the soil. As shown in (Table 3), soil quality is determined by changes in the $\mathrm{P}_{\mathrm{N}}$ value and crops are affected by the degree and accumulation of pollutants.

Table 3. Nemerow composite index as evaluation standard

\begin{tabular}{cccc}
\hline Degree & index & Pollution status & Pollution level \\
\hline I & $\mathrm{P}_{\mathrm{N}} \leq 0.7$ & safe & clean \\
II & $0.7<\mathrm{P}_{\mathrm{N}} \leq 1.0$ & caution & potentially unclean \\
III & $1.0<\mathrm{P}_{\mathrm{N}} \leq 2.0$ & mild contamination & pollution over limit \\
IV & $2.0<\mathrm{P}_{\mathrm{N}} \leq 3.0$ & mid-level pollution & soil, crops subject to severe pollution \\
V & $\mathrm{P}_{\mathrm{N}}>3.0$ & heavy pollution & soil, crops subject to heavy pollution \\
\hline
\end{tabular}

\section{$3 \quad$ Results and Discussion}

\subsection{Analysis of Heavy Metal Content in Samples}

Table 4 lists the heavy metal contents in 22 surface soil samples taken from original cropland. The variable coefficient reflects the average variable degree of sampling points in the total sample. Generally, $10 \% \sim 100 \%$ exhibited medium variation: the variable coefficient for $\mathrm{Cu}$ in samples from original land reached a maximum of $61.48 \%$, and the variable coefficient for As reached a minimum of $8.45 \%$. The heavy metals can be arranged from maximum to minimum degree of variation as follows: $\mathrm{Cd}$, $\mathrm{Zn}, \mathrm{Pb}, \mathrm{Cu}, \mathrm{As}$, and $\mathrm{Cr}$. 
Table 4. Descriptive statistics for heavy metal contents from original land

\begin{tabular}{llllllll}
\hline Element & $\begin{array}{l}\text { Min } \\
(\mathrm{mg} / \mathrm{kg})\end{array}$ & $\begin{array}{l}\text { Max } \\
(\mathrm{mg} / \mathrm{kg})\end{array}$ & $\begin{array}{l}\text { Mean } \\
(\mathrm{mg} / \mathrm{kg})\end{array}$ & SD & $\mathrm{CV}(\%)$ & $\begin{array}{l}\text { Skew- } \\
\text { ness }\end{array}$ & Kurtosis \\
\hline $\mathrm{As}$ & 0 & 26.40 & 15.47 & 8.45 & 8.45 & -0.318 & -0.689 \\
$\mathrm{Cd}$ & 0.14 & 0.42 & 0.30 & 0.077 & 25.49 & -0.847 & 0.095 \\
$\mathrm{Cr}$ & 18.24 & 56.34 & 48.16 & 8.19 & 17.01 & -2.507 & 8.265 \\
$\mathrm{Cu}$ & 13.44 & 90.12 & 28.16 & 17.66 & 61.48 & 2.447 & 6.572 \\
$\mathrm{~Pb}$ & 5.76 & 28.49 & 13.38 & 4.92 & 36.80 & 1.380 & 3.287 \\
$\mathrm{Zn}$ & 30.08 & 61.90 & 44.84 & 9.28 & 20.70 & 0.471 & -0.767 \\
\hline
\end{tabular}

Table 5 lists the heavy metal contents in 50 surface soil samples taken from farm land. The variable coefficient reflects the average variable degree of sampling points in the total sample. The variable coefficient for $\mathrm{Cd}$ reached a maximum of $34.74 \%$, and the variable coefficient for $\mathrm{Cr}$ reached a minimum of $6.15 \%$. The heavy metals can be arranged from maximum to minimum degree of variation as follows: $\mathrm{Cd}, \mathrm{Zn}, \mathrm{Pb}, \mathrm{Cu}$, As, and Cr. Comparison between the two kinds of farmland reveals that the variable coefficients of $\mathrm{Cr}, \mathrm{Cu}, \mathrm{Pb}$, and $\mathrm{Zn}$ decrease over time, but the variable coefficient of $\mathrm{Cd}$ increases significantly after years of farming.

Table 5. Descriptive statistics for heavy metal contents from farm land

\begin{tabular}{llllllll}
\hline Element & $\begin{array}{l}\text { Min } \\
(\mathrm{mg} / \mathrm{kg})\end{array}$ & $\begin{array}{l}\text { Max } \\
(\mathrm{mg} / \mathrm{kg})\end{array}$ & $\begin{array}{l}\text { Mean } \\
(\mathrm{mg} / \mathrm{kg})\end{array}$ & SD & CV $(\%)$ & $\begin{array}{l}\text { Skew- } \\
\text { ness }\end{array}$ & Kurtosis \\
\hline $\mathrm{As}$ & 11.53 & 18.34 & 14.50 & 1.45 & 10.13 & 0.235 & 0.064 \\
$\mathrm{Cd}$ & 0.19 & 1.23 & 0.43 & 0.15 & 35.09 & 3.165 & 16.817 \\
$\mathrm{Cr}$ & 41.78 & 58.12 & 47.13 & 2.90 & 6.21 & 0.896 & 2.709 \\
$\mathrm{Cu}$ & 19.97 & 34.20 & 25.51 & 2.59 & 10.26 & 0.893 & 2.839 \\
$\mathrm{~Pb}$ & 18.19 & 34.18 & 22.17 & 2.28 & 10.39 & 2.775 & 14.466 \\
$\mathrm{Zn}$ & 56.58 & 108.29 & 69.18 & 8.47 & 12.37 & 2.194 & 8.012 \\
\hline
\end{tabular}

\subsection{Spatial Distribution Features of Heavy Metals in Soil}

We used the inverse distance weighting (IDW) method to conduct an interpolation analysis and examine spatial variation in the soil pollutants. As shown in Fig. 1, As content in original soil was greater in the west than in the east, and As content in the southwest region is greater than the natural background value. Few regions reached the level II standard. Cd content in original soil was clearly greater in the southeast and northeast than in other regions. In most areas, $\mathrm{Cd}$ content in soil was greater than the natural background value: in some areas values were greater than 0.40 and reached the level II standard. Cr content in original soil was less than the natural background value, with considerable spatial variation in the north and southwest regions. $\mathrm{Cu}$ content in original soil was highest in most north and northeast areas and the highest point was $90.12 \mathrm{mg} / \mathrm{kg}$, but far lower than the level II standard and did not exceed the natural 
background value. Spatial variation in $\mathrm{Pb}$ content in original land tended to be greater in the north than in the south, and tended to change gradually. Zn content was less than the natural background value, and spatial variations revealed that content tended to be higher in the west than in the east. Zn content was very high in some northeast areas.
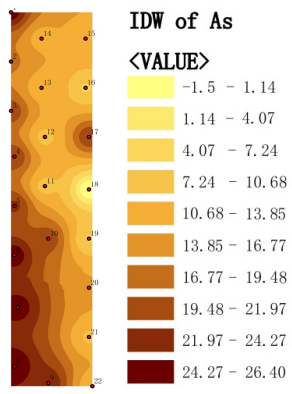

As

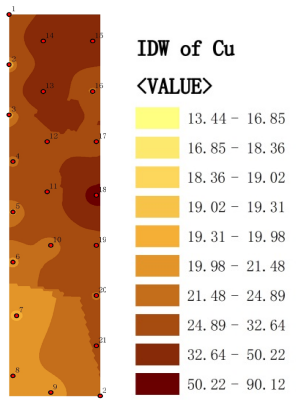

$\mathrm{Cu}$
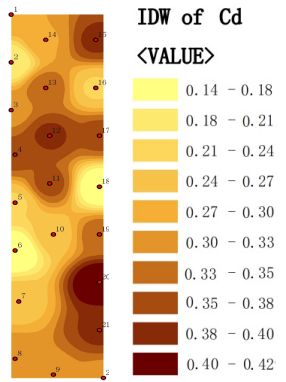

Cd

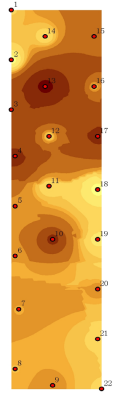

IDW of $\mathrm{Pb}$ 〈VALUE〉
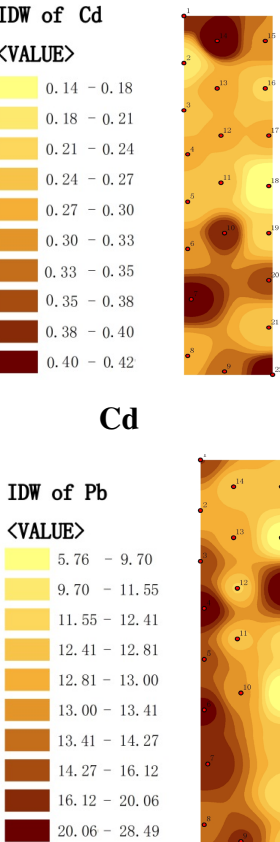

$\mathbf{P b}$

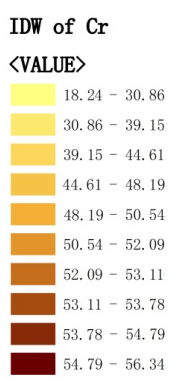

$\mathrm{Cr}$

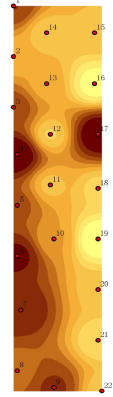

IDW of $\mathrm{Zn}$

〈VALUE〉

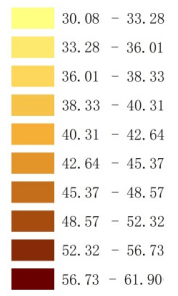

Zn

Fig. 1. The heavy metals content in soil and spatial variation in original land

Fig. 2 shows that As content in farm land was lower than the natural background value; only a few southwest and northwest regions reached the level II standard. Overall $\mathrm{Cd}$ content was greater than the natural background value, with most regions reaching the level II standard. The contents of $\mathrm{Cr}, \mathrm{Cu}$, and $\mathrm{Zn}$ in farm land exhibited a scattered spatial distribution. Generally, the comparisons revealed that in original land, spatial variation was very similar for all heavy metals, gradation levels differed, and the natural status of soil was relative stable. In farm land, heavy metal content exceeded the standard and differed greatly in quantity: $\mathrm{Cr}, \mathrm{As}, \mathrm{Zn}, \mathrm{Pb}$, and $\mathrm{Cu}$ contents were all more than $1.2 \sim 1.7$ times higher than normal, and $\mathrm{Cd}$ content was nearly 5 times the normal value. These findings indicate that farm land has been polluted. 


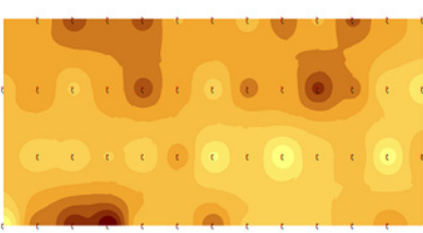

As

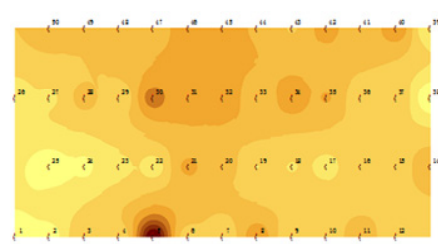

$\mathrm{Cr}$

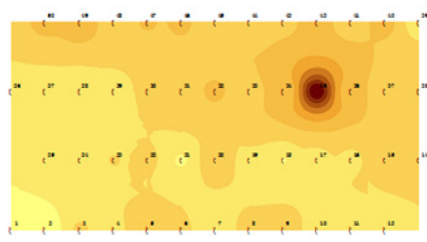

$\mathbf{P b}$
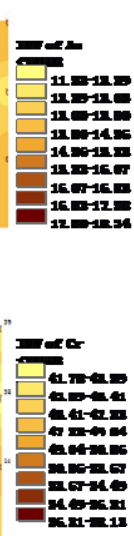

$x=11$

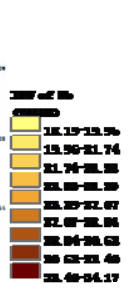

Zn
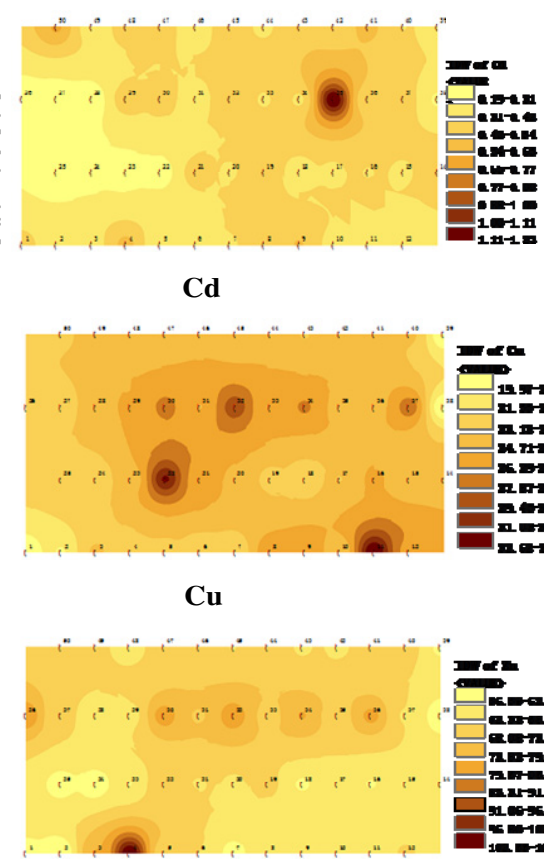

Cd

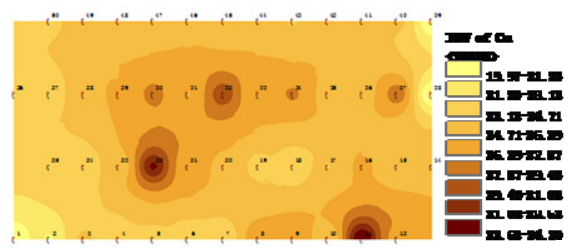

$\mathrm{Cu}$

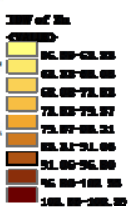

ineras

Fig. 2. The heavy metals content in soil and spatial variation in farm land

\subsection{Soil Heavy Metal Pollution Assessment}

\subsubsection{Soil Heavy Metal Contents Compared with the Standards}

The As from the original land and farm land are both meet to the Green Food standard, but more less than the Pollution-Free Food standard; the $\mathrm{Cr} 、 \mathrm{Cu} 、 \mathrm{~Pb}$ and $\mathrm{Zn}$, from the original land and farm land are all far less than the Pollution-Free Food standard, and less than the Green Food standard (there is not Limited value for the $\mathrm{Zn}$ in the Green Food standard); the $\mathrm{Cd}$ is only $0.30 \mathrm{mg} / \mathrm{kg}$ in original land, both less than the two standards, but it rise to $0.43 \mathrm{mg} / \mathrm{kg}$ in farm land, increased $43 \%$, over the Green Food standard, show that there is accumulation of $\mathrm{Cd}$ in farm land(see Fig. 3).

Unit:mg/kg

\subsubsection{The Superscalar Rate of Soil Heavy Metal According Different Standards} In original land 4 samples exceed the Pollution-free Food Standard and 18 samples exceed Green Food Standard of As, the rate were 10\% and 45\% (Table 6). In farm land 31 samples exceed Green Food Standard of Cd, the rate is 62\% (Table 7), show that there is accumulation of $\mathrm{Cd}$ in farm land. 


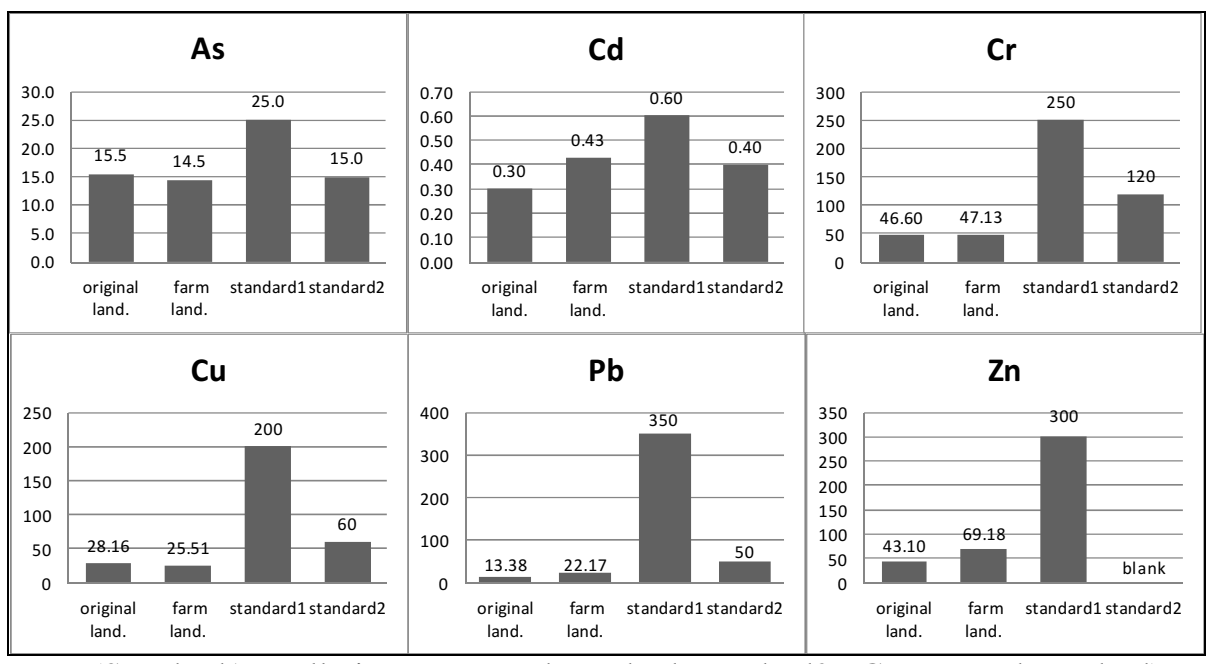

(Standard $1=$ Pollution-Free Food standard, standard2 $=$ Green Food standard $)$

Fig. 3. Comparison of soil heavy metals contents according to different standards

Table 6. The superscalar rate of soil heavy metal in original land

\begin{tabular}{cccccc}
\hline $\begin{array}{c}\text { heavy } \\
\text { meatal }\end{array}$ & samples & \multicolumn{2}{c}{ Pollution-free Food Standard } & \multicolumn{2}{c}{ Green Food Standard } \\
\cline { 3 - 6 } & & Superscalar & $\begin{array}{c}\text { Superscalar } \\
\text { rate }(\%)\end{array}$ & Superscalar & $\begin{array}{c}\text { Superscalar } \\
\text { rate }(\%)\end{array}$ \\
\hline $\mathrm{As}$ & 22 & 4 & 18 & 10 & 45 \\
$\mathrm{Cd}$ & 22 & 0 & 0 & 1 & 5 \\
$\mathrm{Cr}$ & 22 & 0 & 0 & 0 & 0 \\
$\mathrm{Cu}$ & 22 & 0 & 0 & 1 & 5 \\
$\mathrm{~Pb}$ & 22 & 0 & 0 & 0 & 0 \\
$\mathrm{Zn}$ & 22 & 0 & 0 & $/$ & $/$ \\
\hline
\end{tabular}

Table 7. The superscalar rate of soil heavy metal in farm land

\begin{tabular}{llllll}
\hline \multirow{2}{*}{$\begin{array}{c}\text { heavy } \\
\text { meatal }\end{array}$} & samples & \multicolumn{2}{c}{ Pollution-free Food Standard } & \multicolumn{2}{c}{ Green Food Standard } \\
\cline { 3 - 6 } & & Superscalar & $\begin{array}{c}\text { Superscalar } \\
\text { rate }(\%)\end{array}$ & Superscalar & $\begin{array}{c}\text { Superscalar } \\
\text { rate }(\%)\end{array}$ \\
\hline $\mathrm{As}$ & 50 & 0 & 0 & 0 & 0 \\
$\mathrm{Cd}$ & 50 & 2 & 4 & 31 & 62 \\
$\mathrm{Cr}$ & 50 & 0 & 0 & 0 & 0 \\
$\mathrm{Cu}$ & 50 & 0 & 0 & 0 & 0 \\
$\mathrm{~Pb}$ & 50 & 0 & 0 & 0 & 0 \\
$\mathrm{Zn}$ & 50 & 0 & 0 & $/$ & $/$ \\
\hline
\end{tabular}




\subsubsection{Single Pollution Index Evaluation}

With regard to upper limits for elements in the Pollution-Free Food Standard and the Green Food Standard, separate environmental evaluation criteria were used to calculate and analyze factors in the pollution index of heavy metals for soil samples taken from the two study areas. With regard to Pollution-Free Food Standard requirements, the pollution index was less than 1 in all samples from original land. This means that this area meets the Pollution-Free food standard for the six heavy metals investigated. With regard to the Green Food Standard, all pollution indices were also less than 1, indicating that this area also qualifies for the Green Food Standard (see Table 8).

Table 8. Single pollution index evaluation of soil heavy metal in original land

\begin{tabular}{cccc}
\hline Heavy metal & Mean $(\mathrm{mg} / \mathrm{kg})$ & $\begin{array}{c}\text { Pollution-Free food } \\
\text { standards } \\
\text { pollution index }\end{array}$ & $\begin{array}{c}\text { Green Food Standard } \\
\text { pollution index }\end{array}$ \\
\hline $\mathrm{As}$ & 15.47 & 0.62 & 0.77 \\
$\mathrm{Cd}$ & 0.30 & 0.50 & 0.75 \\
$\mathrm{Cr}$ & 46.60 & 0.19 & 0.39 \\
$\mathrm{Cu}$ & 28.16 & 0.14 & 0.47 \\
$\mathrm{~Pb}$ & 13.38 & 0.04 & 0.27 \\
$\mathrm{Zn}$ & 43.10 & 0.14 & $/$ \\
\hline
\end{tabular}

With regard to upper limits for elements in the Pollution-Free Food Standard and the Green Food Standard, separate environmental evaluation criteria were again used to calculate and study analyze factors in the pollution index of heavy metals in 50 surface soil samples taken from farm land. With regard to the Pollution-Free Food Standard requirements, the maximum pollution index was 0.71 and the minimum was 0.06; because these values were less than 1 for all six heavy metals, this area meets Pollution-Free Food Standards. With regard to the Green Food Standard, five heavy metals had a pollution index less than 1, but the index for $\mathrm{Cd}$ was greater than 1 , meaning that the soil is polluted and this area does not meet the Green Food Standards (see Table 9).

Table 9. Single pollution index evaluation of soil heavy metal in farm land

\begin{tabular}{cccc}
\hline Heavy metal & Mean (mg/kg) & $\begin{array}{c}\text { Pollution-Free food standards } \\
\text { pollution index }\end{array}$ & $\begin{array}{c}\text { Green Food Standard } \\
\text { pollution index }\end{array}$ \\
\hline $\mathrm{As}$ & 14.50 & 0.58 & 0.72 \\
$\mathrm{Cd}$ & 0.43 & 0.71 & 1.06 \\
$\mathrm{Cr}$ & 47.13 & 0.19 & 0.39 \\
$\mathrm{Cu}$ & 25.51 & 0.13 & 0.43 \\
$\mathrm{~Pb}$ & 22.17 & 0.06 & 0.44 \\
$\mathrm{Zn}$ & 69.18 & 0.23 & $/$ \\
\hline
\end{tabular}




\subsubsection{Composite Pollution Index Evaluation}

Composite Index is calculated based on Nemerow index method, and the Pollution-Free Food and the Green Food standards. According to the Pollution-Free Food and the Green Food standards the original land soil index were 0.5, 0.7, both in the "clean" level; the farm land were 0.6, 0.9, in the "clean" level according the Pollution-Free Food standard, in the "potentially unclean" leave according to the Green Food standard. (see Table 10).

Table 10. Nemerow index depend on different Standards (mg/kg)

\begin{tabular}{cccccccccccc}
\hline & $\mathrm{As}$ & $\mathrm{Cd}$ & $\mathrm{Cr}$ & $\mathrm{Cu}$ & $\mathrm{Pb}$ & $\mathrm{Zn}$ & Mean & Max & $\begin{array}{c}\text { Nemerow } \\
\text { index }\end{array}$ \\
\hline \multirow{2}{*}{ Pollution-free } & $\begin{array}{c}\text { Original } \\
\text { land }\end{array}$ & 0.62 & 0.5 & 0.19 & 0.14 & 0.04 & 0.14 & 0.27 & 0.62 & 0.5 \\
& $\begin{array}{c}\text { Farm } \\
\text { food standard }\end{array}$ & $\begin{array}{c}\text { land } \\
\text { Original }\end{array}$ & 0.58 & 0.71 & 0.19 & 0.13 & 0.06 & 0.23 & 0.32 & 0.71 & 0.6 \\
& $\begin{array}{c}\text { Origen food } \\
\text { land } \\
\text { Original } \\
\text { standard }\end{array}$ & 0.77 & 0.75 & 0.39 & 0.47 & 0.27 & $/$ & 0.53 & 0.77 & 0.7 \\
\hline
\end{tabular}

\section{Conclusions}

We analyzed data about six heavy metals ( $\mathrm{Cd}, \mathrm{Zn}, \mathrm{Pb}, \mathrm{Cu}, \mathrm{As}$, and $\mathrm{Cr}$ ) and found that the Nuomuhong farm original land soil is pure and can comply with the Pollution-Free Food Standard and the Green Food Standard, but the farmland were subject to pollution during many years of farming, which resulted in heavy metal pollution, especially $\mathrm{Cd}$ pollution. Further research will be required to clarify the process of pollution.

We analyzed soil from two different areas of Nuomuhong Farm: original land and farm land, in terms of their heavy metal $(\mathrm{Cd}, \mathrm{Zn}, \mathrm{Pb}, \mathrm{Cu}, \mathrm{As}$, and $\mathrm{Cr}$ ) content. We used the Nemerow composite index to analyze and evaluate data. According to the Pollution-Free Food Standards, the soils in Nuomuhong Farm are all near or below excessive levels, and according to the Green Food Standard, original soil is all considered clean, whereas the farm land is at a borderline excessive level.

Acknowledgment. This research was funded by the Xinjiang Production and Construction Corps major science and technology program "precision agriculture and information on agricultural technology application and demonstration" ( 2007zx03 ). The authors would like to thank Prof. Dezhao Chi from Qinghai university for his good suggestion regarding article writing, and Dr. Hairong Lin from Shihezi university for her chemical analysis.

\section{References}

1. Bai, Y., Li, B., Hu, K.: Study on the space variable character of soil salt and its component in Huanghuaihai Plain. Soil Environmental Quality Standards (1999) (in Chinese)

2. Qu, M., Li, W., Zhang, C.: Spatial Distribution and Uncertainty Assessment of Potential Ecological Risks of Heavy Metals in Soil Using Sequential Gaussian Simulation. Human and Ecological Risk Assessment (2013) 
3. Zhang, L., Liang, J., Wu, C., et al.: Evaluation and concentration of soil heavy metals in apple orchards in Shanxi province. Journal of Fruit Science 21(2), 103-105 (2004) (in Chinese)

4. Wu, G., Li, L., Hao, M., et al.: Effects of Long-term Fertilization on Heavy-metal Contents of Soil and Environmental Quality Evaluation. Journal of Soil and Water Conservation 6(24-3), 60-63 (2010) (in Chinese)

5. Huang, X., Li, T., Yu, H.: Risk assessments of heavy metals in typical greenhouse soils. Plant Nutr. Fert. Sci. 16(4), 833-839 (2010) (in Chinese)

6. Wu, G., Tang, H., Li, R.: The current situation of the development of Ningxia medlar in Qinghai. Ningxia Agriculture and Forestry Science and Technology 2, 62-63 (2008) (in Chinese)

7. Ministry of Agriculture of the People's Republic of China. Pollution-free food wolfberry production technology standard procedures-NY/T 5249-2004. Standards Press of China, Bejing (2004)

8. Ministry of Agriculture of the People's Republic of China. Environmental technical terms for green-food production area -NY/T 3912-2000. In: Green-food Standard Collection. pp. 86-90. Standards Press of China, Bejing (2003) 